\title{
PEMBERIAN PROGESTERON PADA KEGUGURAN BERULANG
}

\author{
Erna Suparman \\ Eddy Suparman
Bagian Obstetri dan Ginekologi Fakultas Kedokteran Universitas Sam Ratulangi Manado
Email: ernasuparman@yahoo.com

\begin{abstract}
Recurrent pregnancy loss (RPL) occurs in $0.5-1 \%$ of partners. The pathophysiology of this RPL is complex. The causes include anatomical, genetic and molecular abnormalities, endocrine disorders, thrombophilia, and the anti-phospholipid syndrome, meanwhile in $50 \%$ of cases no cause can be identified. Progesterone is needed to create a suitable environment for the implantation. Low progesterone level during early pregnancy may reflect corpus luteum defects or abnormal products of conception. Besides that, low progesterone is a sign of a coming miscarriage; an administration of progesterone can only delay the onset of bleeding.. Even with a normal plasma progesterone levels, endometrial progesterone deficiency can still result from receptor defects; this finding supports the existence of absolute or relative progessterone deficiency as a cause of spontaneous abortion. Women who suffer from relative progesterone deficiency probably will not get any benefit from progesterone therapy. Almost all current research states that there is no difference in the rates of miscarriages in women treated and not treated with progesterone. Therefore, all medical organizations do not recommend progesterone supplementation to recurrent miscarriage, except in women who use reproductive technologies such as in vitro fertilization (IVF).
\end{abstract}

Keywords: recurrent pregnancy loss, progesterone.

\begin{abstract}
Abstrak: Keguguran berulang terjadi pada $0,5-1 \%$ pasangan dengan patofisiologi yang kompleks. Sebagai penyebab ialah kelainan anatomi, genetik dan molekuler, gangguan endokrin, thrombofilia, dan sindrom anti-fosfolipid, tetapi pada $50 \%$ kasus tidak jelas. Progesteron sangat diperlukan dalam menciptakan lingkungan yang cocok untuk implantasi endometrium. Konsentrasi progesteron yang rendah selama awal kehamilan mencerminkan defek korpus luteum atau hasil konsepsi yang abnormal. Progesteron yang rendah merupakan tanda dari keguguran akan datang namun pemberian progesteron hanya dapat menunda timbulnya perdarahan. Walaupun tingkat progesteron plasma normal, endometrium masih dapat mengalami kekurangan progesteron akibat defek reseptor. Temuan ini mendukung adanya defisiensi progesteron absolut atau relatif sebagai penyebab keguguran spontan. Wanita yang menderita kekurangan progesteron relatif tidak akan mendapatkan keuntungan dari pemberian progesteron. Hampir semua penelitian saat ini menyatakan bahwa tidak terdapat perbedaan tingkat keguguran pada wanita yang diberikan progesteron dan yang tidak; oleh karena itu semua organisasi medis tidak menganjurkan pemberian progesteron pada keguguran berulang, kecuali pada wanita yang menggunakan teknologi reproduksi seperti IVF.
\end{abstract}

Kata kunci: keguguran berulang, progesteron.

Keguguran berulang yang didefinisikan sebagai tiga atau lebih keguguran berturutturut sebelum minggu ke-20 kehamilan, terjadi pada $0,5-1 \%$ pasangan. ${ }^{1,2}$ Menurut
HIFERI-POGI, keguguran berulang (recurrent pregnancy loss, recurrent miscarriage) adalah kejadian keguguran paling tidak sebanyak dua kali atau lebih 
berturut-turut pada usia kehamilan kurang dari 20 minggu dan/atau berat janin kurang dari 500 gram. Risiko setelah dua kali keguguran berturut-turut sama dengan resiko keguguran tiga kali berturut-turut, yaitu sekitar 30\%.,

Keguguran berulang primer mengacu pada wanita yang belum pernah berhasil pada kehamilan sebelumnya, sedangkan keguguran berulang sekunder mengacu pada keguguran setelah kelahiran hidup sebelumnya. Prognosis yang lebih baik telah dilaporkan untuk keguguran berulang sekunder daripada keguguran berulang primer. $^{1}$

Dari seluruh faktor yang berpengaruh, penyebab keguguran berulang yang tidak terbantahkan ialah genetik (translokasi kromosom pada salah satu pasangan, peningkatan prevalensi oosit aneuploidi yang berhubungan dengan umur ibu), anatomik (abnormalitas uterus didapat atau kongenital), atau imunologik (komplikasi trombotik dari sindroma antifosfolipid). Selain itu, alo-imunopatologi, trombofilia kongenital (Faktor V dan lainnya), endokrinopati (kelainan tiroid, diabetes, defisiensi fase luteal), infeksi (mikoplasma genital), dan paparan lingkungan (merokok, konsumsi alkohol atau kafein berlebihan) turut berperan. Abnormalitas uterus kongenital paling sering dihubungkan dengan keguguran pada trimester kedua. ${ }^{5-7}$

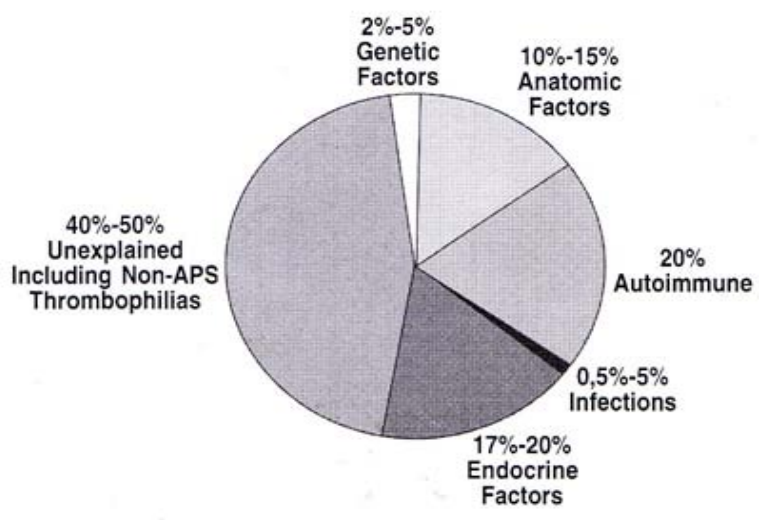

Gambar 1. Faktor-faktor penyebab keguguran berulang. Sumber: Stephenson dan Kutteh, 2007. ${ }^{7}$
Dewasa ini, semua organisasi medis tidak menganjurkan pemberian progesteron pada wanita dengan keguguran berulang, kecuali pada wanita yang menggunakan teknologi reproduksi seperti in vitro fertilization (IVF). Hampir semua penelitian menyatakan bahwa tidak terdapat perbedaan dalam tingkat keguguran pada wanita yang mendapatkan suplemen progesteron dan yang tidak. Terdapat beberapa penelitian yang mengemukakan bahwa pemberian progesteron mungkin bermanfaat pada wanita yang pernah mengalami keguguran berulang, tetapi untuk kemaknaannya masih diperlukan penelitian lebih lanjut. ${ }^{8,9}$

Data prognosis keguguran berulang menunjukkan bahwa rerata angka kelahiran hidup untuk wanita dengan keguguran berulang ialah $75 \%$ pada kehamilan berikutnya, dengan angka keguguran 20\% hingga usia kehamilan 9 minggu, dan angka keguguran 5\% setelah periode tersebut. Selain itu, prognosis juga bervariasi tergantung pada usia ibu dan jumlah keguguran sebelumnya. ${ }^{10}$

\section{DEFEK FASE LUTEAL DAN GANGGUAN PERKEMBANGAN ENDOMETRIUM}

\section{Defek fase luteal dan progesteron}

Konsentrasi progesteron pada kehamilan awal merefleksikan kombinasi kontribusi dari korpus luteum dan trofoblas yang saling tumpang tindih. Konsentrasi progesteron serum berfluktuasi secara luas dan tidak dapat dinterpretasikan karena sekresi progesteron korpus luteum bersifat pulsatil. Diagnosis pasti defek fase luteal yang menyebabkan keguguran berulang adalah melalui biopsi endometrium, yang dilakukan pada hari ke-26 dan ke-28 daur haid atau 12 hari dari kenaikan suhu basal badan. Pengambilan jaringan dilakukan pada daerah fundus bagian depan karena bagian ini bersifat sangat responsif terhadap perubahan siklus hormonal ovarium. Tindakan biopsi endometrium merupakan tindakan invasif dengan biaya 
mahal. Selain dengan biopsi, alternatif lain ialah dengan mengukur kadar progesteron serum. Pertanda adanya defek fase luteal ialah bila ditemukan kadar progesteron $<10$ $\mathrm{ng} / \mathrm{ml}$ satu minggu menjelang haid yang akan datang, atau 5-7 hari setelah puncak luteinizing hormone (LH). ${ }^{11,12}$

Sekresi progesteron bersifat pulsatil; oleh karena itu pemeriksaan tunggal progesteron selama fase luteal memiliki nilai diagnostik yang kecil atau bahkan tak bernilai untuk diagnosis defek fase luteal. Penelitian Abraham et al. menyarankan untuk melakukan pengambilan sampel sebanyak tiga kali pada pertengahan fase luteal jika ingin mengetahui fungsi korpus luteum yang akurat. Pada studi oleh Jordan et al., dilakukan pemeriksaan progesteron hari ke-6, 7, dan 8 fase luteal dan dianggap memiliki sensitivitas $100 \%$ dan spesifisitas 80\% dengan cut-off point pada penjumlahan ketiga hasil pemeriksaan $30 \mathrm{ng} / \mathrm{ml}^{11}$

Skrining defek fase luteal lebih dianjurkan untuk kasus keguguran berulang. Semua wanita yang telah didiagnosis defek fase luteal sebaiknya melakukan pemeriksaan lanjutan thyroid stimulating hormone (TSH) dan prolaktin untuk mengetahui ada tidaknya gangguan tiroid dan prolaktinemia. Kedua gangguan tersebut dapat memengaruhi fungsi luteal wanita usia reproduktif. ${ }^{11}$

Pemberian hormon gonadotropin akan memicu sintesis progesteron sehingga dapat memperbaiki defek fase luteal. Pemakaian antagonis gonadotropin releasing hormone $(\mathrm{GnRH})$ dapat digunakan untuk memicu pengeluaran LH dan memiliki keunggulan dibandingkan agonis GnRH yaitu dapat diberikan dalam waktu singkat atau saat diduga akan terjadi $L H$ surge, waktu paruh singkat, dan penekanan sekresi LH dan follicle stimulating hormone (FSH) sangat singkat. Beberapa peneliti memilih untuk memberikan terapi defek fase luteal dengan suplementasi progesteron eksogen mulai hari ke-2 sampai ke-3 setelah ovulasi, tetapi pendekatan ini sering menghambat menstruasi sehingga menciptakan pengharapan kehamilan yang palsu, menambah rasa stres, dan mengundang kekecewaan. ${ }^{5}$

Penelitian prospektif oleh Ogasawara et al. $^{13}$ terhadap 197 wanita dengan keguguran berulang menyimpulkan bahwa kadar progesteron, estrogen (E2), dan rasio P/E2 tidak dapat memrediksikan keguguran pada kehamilan berikutnya.

\section{Kekurangan progesteron dan keguguran berulang}

Beberapa studi melaporkan konsentrasi progesteron serum yang lebih rendah dari normal pada pasien keguguran berulang dengan defek endometrium, dibandingkan dengan yang mempunyai endometrium normal. Pada tingkat progesteron plasma normal, endometrium masih dapat mengalami kekurangan progesteron akibat defek reseptor. Li et al. menunjukkan bahwa endometrium sekitar $25 \%$ wanita dengan keguguran berulang menunjukkan perbedaan ekspresi reseptor progesteron dibandingkan kontrol normal. ${ }^{12,14}$

Mutasi dari gen reseptor progesteron juga dapat berkontribusi terhadap gangguan fungsi reproduksi dan mengakibatkan keguguran dini. Schweikert et al. melaporkan polimorfisme dalam urutan pengkodean gen reseptor progesteron manusia dengan frekuensi lebih tinggi secara bermakna pada pasien yang mengalami keguguran berulang dibandingkan kelompok kontrol. Hambatan perkembangan endometrium terjadi pada defek reseptor progesteron sebagai dasar walaupun konsentrasi progesteron memadai.Temuan ini mendukung adanya defisiensi progesteron absolut atau relatif sebagai penyebab abortus spontan. Pemberian progesteron pada defisiensi progesteron absolut berpotensi sukses. ${ }^{1,15}$

\section{PENGARUH PROGESTERON TER- HADAP SISTEM IMUN TUBUH}

\section{Hubungan imunologi feto-maternal}

Sejumlah $50 \%$ dari antigen fetal berasal dari ayah. Terdapatnya antibodi anti-fetal, anti-plasenta, dan anti-paternal dalam serum wanita dengan kehamilan yang berhasil jelas menunjukkan bahwa 
pengenalannya terhadap antigen janin tidak membahayakan kehamilan, melainkan menyebabkan perubahan fungsional yang memungkinkan janin untuk bertahan hidup dan berkembang. ${ }^{1}$

Selama fase luteal dari siklus ovarium, respon kekebalan tubuh bergeser ke arah respon Th2. Penelitian prospektif oleh Kruse et al. $^{16}$ menemukan rasio sitokin Th1/Th2 umumnya lebih rendah pada pasien dengan keguguran berulang yang disertai kadar serum progesteron yang tinggi; hal ini menunjukkan bahwa progesteron serum mungkin memiliki pengaruh pada produksi sitokin. Didrogesteron yang merupakan derivat progesteron, pada wanita dengan persalinan prematur menghambat produksi sitokin pro-inflamasi dan meningkatkan produksi sitokin antiinflamasi. ${ }^{1,16,17}$

Pengaruh progesteron pada sistem kekebalan tubuh ibu hamil dimediasi oleh reseptor. Setelah pengenalan antigen janin, sel $\mathrm{T} \quad \mathrm{\gamma} / \mathrm{d}$ ibu yang telah diaktifkan mengekspresikan reseptor progesteron yang setelah terikat dengan progesteron menghasilkan mediator progesterone-induced blocking factor (PIBF) ${ }^{18}$ Penelitian pada hewan coba menggunakan tikus hamil memperlihatkan netralisasi aktivitas PIBF endogen oleh antibodi spesifik anti-PIBF yang menyebabkan penurunan bermakna jumlah janin yang dapat hidup hingga akhir kehamilan; hal ini dikaitkan dengan peningkatan kegiatan sel natural killer (NK) limpa. Data ini menunjukkan bahwa pada tikus PIBF berkontribusi terhadap keberhasilan kehamilan, dan bahwa sebagian besar dari efek pelindung kehamilan terletak pada penekanan aktivitas sel NK. ${ }^{1}$

Respon imun humoral meningkat selama kehamilan, sedangkan respon imun seluler dan penyakit autoimun yang dimedasi sel mengalami down-regulation. Bukti klinis menunjukkan bahwa wanita hamil mengalami perubahan imunologik yaitu penurunan respon Th1 dan peningkatan respon Th2, sehingga suksesnya kehamilan berhubungan atau bergantung pada stimulasi produksi sitokin Th2. Sejumlah studi menunjukkan bahwa pro- duksi yang dominan dari sitokin Th2 tampak pada kehamilan normal, sedangkan kelebihan sitokin Th1 menyebabkan terminasi kehamilan. Wanita dengan keguguran berulang telah terbukti memiliki profil dominasi Th1 atau sitokin pro-inflamasi. ${ }^{19-21}$

\section{PEMBERIAN PROGESTERON PADA KEGUGURAN BERULANG CLINICAL TRIALS}

Kadar progesteron yang rendah pada kehamilan sangat berhubungan dengan keguguran, tetapi penyebabnya masih kontroversial. Di satu sisi, kadar progesteron yang terlalu rendah (akibat kurangnya produksi dari ovarium) secara teoritis dapat menyebabkan keguguran akibat rahim tidak siap untuk mendukung kehamilan. Di sisi lain, banyak dokter yakin bahwa kadar progesteron rendah berarti bahwa keguguran akan segera terjadi. Kadar progesteron yang rendah merupakan tanda pertama bahwa tubuh sedang mempersiapkan untuk terjadinya keguguran pada kehamilan yang telah gagal (misalnya karena kelainan kromosom), dan pada kasus demikian pemberian progesteron tidak bermanfaat. ${ }^{9}$

Pengobatan progesteron dapat bermanfaat jika kelanjutan kehamilan terancam oleh kurangnya produksi progesteron, yang mungkin mengakibatkan perkembangan endometrium yang tidak sesuai, atau kegagalan sistem kekebalan tubuh untuk beradaptasi dengan situasi baru yang diciptakan oleh kehadiran janin. ${ }^{1}$

\section{Progestogen dibandingkan dengan plasebo atau kontrol untuk mencegah keguguran}

Selama lima dekade progesteron telah digunakan untuk mencegah keguguran pada trimester I dan II. Pada penelitian awal pemberian progesteron meningkatkan hasil akhir pada wanita yang terancam kehamilannya. Penelitian ini dilakukan oleh Swyer dan Daley (1953), Goldzieher (1964), dan Le Vine (1964) yang melibatkan 91 wanita dengan keguguran berulang, dan memperlihatkan bahwa pemberian 
progestogen menunjukkan penurunan bermakna pada tingkat keguguran dibandingkan dengan plasebo atau tanpa pengobatan. Semua meta-analisis yang disebutkan di atas telah berusia lebih dari 40 tahun, dan desain dari studi ini tidak dapat diterima oleh standar modern. Sebagai contoh: penelitian Swyer dan Daley tidak menggunakan kontrol plasebo dan metode pengacakan tidak disebutkan sedangkan studi Goldzieher dan Le Vine dilakukan secara randomized placebo-control dan double-blinded, tetapi keduanya memiliki alokasi metodologi yang tidak jelas. ${ }^{1}$

Dua meta-analisis dari randomized trials antara Goldstein et al. (1989) dan Daya (1989) memberikan hasil yang bertentangan. Hasil meta-analisis dari Goldstein et al. menunjukkan bahwa progesteron tidak bermanfaat untuk menjaga kehamilan awal, sedangkan Daya melaporkan bahwa pemberian progesteron meningkatkan keberhasilan kehamilan pada wanita dengan keguguran berulang. Dalam meta-analisis oleh Daya, tiga penelitian terkontrol mengenai pemberian progesteron pada wanita dengan keguguran berulang telah menunjukkan sedikit (tetapi tidak bermakna secara statistik) kenaikan angka kehamilan yang berlanjut melampaui 20 minggu dalam kelompok perlakuan. ${ }^{1}$

Sebuah meta-analisis yang dilakukan oleh Oates-Whitehead et al. (2003) dari 14 penelitian yang melibatkan 1988 wanita mengungkapkan tidak terdapat perbedaan bermakna dalam risiko keguguran antara progestogen dan plasebo atau kelompok pengobatan. ${ }^{1}$ Meta-analisis Cochrane 2008 melibatkan 15 studi yang mencakup 2118 wanita menunjukkan tidak terdapat perbedaan bermakna dalam tingkat keguguran antara kelompok progestogen dan kelompok plasebo. $^{22}$

Meskipun dalam meta-analisis penelitian yang lalu progesteron menyebabkan penurunan yang signifikan pada tingkat keguguran dibandingkan plasebo atau tanpa pemberian progesteron, hasil meta-analisis saat ini menunjukkan bahwa progesteron tidak mengurangi tingkat keguguran.
Sebuah studi multisenter besar (PROMISE) saat ini sedang berlangsung untuk menilai kembali manfaat pemberian progesteron pada wanita dengan riwayat keguguran berulang. ${ }^{9,11}$

Pemberian progestogen selama trimester pertama dan kedua kehamilan dalam upaya mencegah keguguran menunjukkan bahwa pengobatan ini tidak terkait dengan efek samping pada ibu. Carmichael et al. melaporkan bahwa asupan progestin pada awal kehamilan dikaitkan dengan peningkatan risiko hipospadia pada janin lakilaki. ${ }^{1,11}$

\section{SIMPULAN}

Defisiensi progesteron absolut atau relatif (akibat defek reseptor) merupakan salah satu penyebab abortus. Pemberian progesteron pada defisiensi progesteron absolut berpotensi sukses. Dewasa ini, semua organisasi medis tidak menganjurkan pemberian progesteron pada wanita dengan keguguran berulang, kecuali pada yang menggunakan teknologi reproduksi seperti IVF. Hampir semua penelitian menyatakan bahwa tidak terdapat perbedaan dalam tingkat keguguran pada wanita yang diberikan progesteron dan yang tidak.

\section{DAFTAR PUSTAKA}

1. Szekeres J, Balasch J. Progestagen therapy for recurrent miscarriage. Human reproduction update [serial online]. 2008 [cited 2012 Dec 20]; 14(1):27-35. Available from: http://humupd.oxford journals.org/content/14/1/27.full.pdf.

2. The investigation and treatment of couples with recurrent first-trimester and second-trimester miscarriage [homepage on the Internet]. c2011 [updated 2011 Apr 17; cited 2012 Dec 20]. Available from: http://www.rcog. org.uk/womens-health/clinical-guidan ce/investigation-and-treatment-couplesrecurrent-miscarriage-green-top.

3. Hasil Lokakarya Himpunan Endokrinologi Reproduksi dan Fertilitas Perkumpulan Obstetri dan Ginekologi Indonesia 
(HIFERI-POGI). Yogyakarta, 19 Juni 2010.

4. Halvorson LM. First-trimester abortion. In: Schorge J, Joseph IS, Halvorson LM, Hoffman BL, Bradshaw KD, Cunningham G, editors. Williams Gynecology. New York: Mcgraw Hill, 2008; p.298-333.

5. Fritz MA, Speroff L. Clinical Gynecologic Endocrinology and Infertility (Eight Edition). Philadelphia: Lippincott Williams \& Wilkins; 2011.

6. Rao KA, Pillai JR. Recurrent pregnancy loss. J Indian Med Assoc. 2006; 104(8):458-61.

7. Stephenson M, Kutteh W. Evaluation and management of recurrent early pregnancy loss. Clin Obstet Gynecol. 2007; 50(1):132-45.

8. Kiwi R. Recurrent pregnancy loss: etiology and discussion of the causes and their management. Clinical Obstetrics and gynecology. 2006;73(10):913-21.

9. Danielsson K. Using progesterone to prevent miscarriages [homepage on the Internet]. 2010 [updated 2010 Jun 10; cited 2013 Jan 4]. Available from: http://miscarriage.about.com/od/twoor moremiscarriages/i/progesterone.htm.

10. Duckitt K, Qureshi A. Recurrent miscarriage. Clin Evid (Online) [serial online]. 2008 [cited 2013 Jan 4]; 2008;2008:1409. Available from: http://www.ncbi.nlm.nih.gov/pmc/articl es/PMC2907979/.

11. Miller P, Soules $\mathbf{M}$. Luteal phase deficiency: Pathophysiology, diagnosis and treatment. Glob. libr. women's med [homepage on the Internet]. c2009 [updated 2009 May; cited 2012 Dec 20]. Available from: http://www. glowm.com/index.html?p=glowm.cml/s ection_view\&articleid=326.

12. Groom KM. Pharmacological prevention of prematurity. Best Parct Res Clin Obstet Gynecol. 2007;21:843-56.

13. Ogasawara $M$, Shoji $K$, Kinue $K$, Tomomi A, Koji A. Are serum progesterone levels predictive of recurrent miscarriage in future pregnancies?. Fertility and Sterility [serial online]. c1997 [cited 2013 Jan 4]; 68(5):806-9. Available from http://www.fertstert.org/article/S00150282(97)00328-2/pdf.
14. Li TC, Tuckerman EM, Laird SM. Endometrial factors in reccurent miscarriage. Hum Reprod Update. 2002;1:43-52.

15. Schweikert A, Rau T, Berkholz A, Allera A, Daufeld S, Wildt L. Association of progesterone receptor polymorphism with recurrent abortions. Eur J Obstet Gynecol Reprod Biol. 2004;113:67-72.

16. Kruse C, Varming K, Christiansen OB. Prospective, serial investigations of invitro lymphocyte cytokine production, CD62L expression and proliferative response to microbial antigens in women with reccurent miscarriage. Hum Reprod. 2003;18:2465-72.

17. Raghupathy R, Al Mutawa E, Maksheed M, Al-Azemi M, Azizeh $F$. Redirection of cytokine production by lymphocytes from women with preterm delivery by dydrogesterone. Am J Reprod Immunol. 2007;58:31-8.

18. Polgar B, Kispal Gy, Lachmann M, Paar C, Nagy E, Csere P, et al. Molecular cloning and immunological characterization of a novel cDNA coding for PIBF. J Immunol. 2003;171:5956-63.

19. Raghupathy R, Al Mutawa E, Makhseed M, Azizieh F, Szekeres-Bartho J. Modulation of cytokine production by dydrogesterone in lymphocytes from women with recurrent abortion. $\mathrm{Br} \mathrm{J}$ Obstet Gynecol. 2005;45:229-36.

20. Wilson B, Moor J, Jenkins C, Miller H, Walker JJ, McLean MA, et al. Abnormal first trimester serum interleukin 18 levels are associated with a poor outcome in women with a history of reccurent miscarriage. Am JReprod Immunol. 2004;51:156-9.

21. Hanna J, Goldman-Wohl D, Hamani Y, Avraham I, Greenfield C, Nathanson-Yaron S, et al. Decidual NK cells regulate key developmental processes at the human fetal-maternal interface. Nat Med [serial online]. 2006 [cited 2012 Dec 20];12:1065-74. Avaliable from: http://www.nature. com/ nm/journal/v12/n9/pdf/nm1452.pdf.

22. Haas DM, Ramsey PS. Progestogen for preventing miscarriage. Cochrane Database of Systematic. Reviews 2008, Issue 2. Art. No.: CD003511. DOI: 10.1002/14651858.CD003511.pub2. 